\title{
Retrospective Evaluation of Laboratory, Radiological and Clinical Findings of COVID-19 Suspected Cases with a Public Health Perspective in Adiyaman Training and Research Hospital
}

\author{
Adıyaman Eğitim Araştırma Hastanesine Başvuran COVID-19 Şüpheli \\ Vakaların Laboratuvar, Radyolojik ve Klinik Bulgularının Halk Sağlığı \\ Bakışıyla Retrospektif Değerlendirilmesi
}

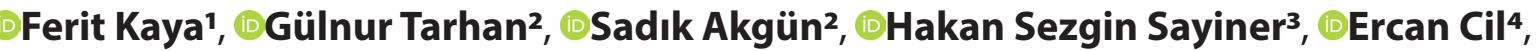 \\ -Ugur Lok ${ }^{5}$, $\odot$ Safiye Kafadar', $\odot$ Furkan Bakirhan' \\ 'Adıyaman Universitesi, Faculty of Medicine, Department of Public Health, Adıyaman,Turkey \\ ${ }^{2}$ Adıyaman University Faculty of Medicine, Department of Clinical Microbiology Adıyaman, Turkey \\ ${ }^{3}$ Adıyaman University Faculty of Medicine, Department of Infectious Diseases, Adıyaman, Turkey \\ ${ }^{4}$ Adıyaman University Faculty of Medicine, Department of Chest Diseases, Adıyaman, Turkey \\ ${ }^{5}$ Adıyaman University Faculty of Medicine, Department of Emergency' Adıyaman, Turkey \\ ${ }^{6}$ Adıyaman University Faculty of Medicine, Department of Radiology Adıyaman, Turkey
}

\begin{abstract}
Aim: The purpose of this study is to evaluate SARS-CoV-2 cases based on clinical evidence from the perspective of public health.

Material and Method: This study is a retrospective study.The data of 354 people were analyzed which were among the patients admitted to the pandemic hospital in Adiyaman in the study.

Results: $70.6 \%$ of those admitted to the hospital with suspected COVID-19, $60 \%$ of those received inpatient treatment and $61.3 \%$ of those who were PCR-positive were male. The median age of those admitted to the hospital was 37 years. $90 \%$ were in a good general condition. The median length of hospitalization was 7 days. $14.8 \%$ PCR-positive patients required mechanical ventilation. Generally, D-dimer, CRP and WBC levels were poor, which were higher in those receiving intensive care $(p<0.05) .19 .5 \%$ of the cases were diagnosed with pneumonia as a result of the CT. COVID 19 was the most common diagnosis as a result of CT (11.0\%).

Conclusion: The disease seems to be more common among men. CT abnormalities are common. D-Dimer, CRP and WBC levels are associated with severe disease.
\end{abstract}

Keywords: Communicable diseases, public health, COVID-19
Öz

Amaç: Bu çalışmanın amacı, SARS-CoV-2 vakalarını halk sağlığı perspektifinden klinik kanıtlara dayalı olarak değerlendirmektir.

Gereç ve Yöntem: Bu çalışma retrospektif tiptedir Araştırmada Adıyaman pandemi hastanesine başvuran hastalardan 354 kişinin verileri incelendi.

Bulgular: Hastaneye COVID-19 şüphesi ile başvuranların \%70,6'sı, yatarak tedavi görenlerin \%60'ı ve PCR pozitif olanların\% 61,3'si erkekti. Hastaneye başvuranların ortanca yaşı 37 idi. \% 90'ı genel olarak iyl durumdaydı. Ortanca hastanede kalış süresi 7 gündü. PCR pozitif hastaların\% 14.8'i mekanik ventilasyona ihtiyaç duydu. Genel olarak D-dimer, CRP ve WBC seviyeleri zayıftı ve yoğun bakım alanlarda daha yüksekti ( $p<0.05$ ) BT sonucunda vakaların\% 19,5'i pnömoni tanısı aldı. BT sonucuna göre COVID 19 en yaygın tanıydı (\% 11.0).

Sonuç: Hastalık erkekler arasında daha yaygın görünmektedir. BT anormallikleri yaygındır. D-Dimer, CRP ve WBC seviyeleri ciddi hastalıkla ilişkilidir.

Anahtar Kelimeler: BulaşıCı hastalıklar, halk sağlığı, COVID-19 


\section{INTRODUCTION}

The COVID-19 outbreak emerged in late 2019 and has spread to all over the world very rapidly and has become a pandemic. ${ }^{[1]}$ The infection has transmitted from human to human and spread from China to the continents of Asia, Europe and Africa infecting millions and killing tens of thousands of people. The 2019 n-CoV has impacted many countries and it presents a major public health issue. The index case in Turkey was identified on March 11,2020 and the index case in the study region was identified on March 14, 2020. The average incubation period is 2 to 4 days. ${ }^{[2]}$ In their study, Lauer et al. ${ }^{[3]}$ found that less than $2.5 \%$ of infected people develop symptoms in 2.2 days while $97.5 \%$ in 11.5 days. The median incubation period was found to be 5.1 days

According to the joint report of WHO and China, the majority of the cases were between the ages of 30 and 69 and the median age was $51 .{ }^{[4]}$ In terms of clinical course, the disease can cause as far as multi organ failure.$^{[5]}$ In severe disease, clinical signs such as fever, shortness of breath, tachypnea and hypoxia present. In addition to clinical signs, radiological signs also help support the diagnosis. ${ }^{[5]}$ The study of Pan et al. ${ }^{[6]}$ showed that $48 \%$ of the cases had mild disease, $29.9 \%$ moderate, $19.1 \%$ severe and $3 \%$ critical. $41.3 \%$ of the severe and critical cases was people over the age of 80 .

Various immunological tests and Polymerase Chain Reaction (PCR) test, which targets specific genes, are performed to diagnose the infection. The most ideal diagnostic method for COVID-19 is quantitative real-time polymerase chain reaction (qRT-PCR) along with nasopharyngeal swab. Symptoms, risk factors, pneumonia findings and thorax CT images should also be taken into consideration when diagnosing the infection. Although PCR tests have high sensitivity, the fact that results are obtained 4 to 6 hours (reduced to 2-4 hours in recent kits) and experienced staff is required for application has led to the production of rapid antibody (immunoassay) tests. These tests can detect lgM and IgG antibodies, which are produced against SARS-CoV-2, in 15 minutes. ${ }^{[2]}$ The purpose of this study is to evaluate SARS-CoV-2 cases based on clinical evidence from the perspective of public health. The purpose was to analyze cases admitted to the hospital and collect data on the COVID-19 infection, compile and interpret the data and contribute to the literature.

Pandemics affect men and women differently. The exposure risk and biological sensitivity may be different due to the other social factors as well as infections, social and economic results and the gender of an individual. Different sample groups or underreporting may be the reasons behind these differences

It is aimed to examine the suspected COVID-19 cases admitted to the Adıyaman Training and Research Hospital in terms of clinical, radiological and laboratory findings.

\section{MATERIAL AND METHOD}

\section{Research type}

This study is a retrospective study.

\section{The universe and sample of the research}

3064 individuals, who registered to Adiyaman Training and Research Hospital during the course of 3 months starting with the first case admitted on March 14, 2020, formed the universe of the study. The formula $n=\mathrm{Nt} 2 \mathrm{pq} / \mathrm{d} 2(\mathrm{~N}-1)+\mathrm{t} 2 \mathrm{pq}$ was used to determine the sample size, which was calculated to be 354 with a confidence interval of $95 \%$, prevalence of $50 \%$ and deviation of $5 \%$. The stratified sampling method was made use of. Using the open epi program, random numbers were generated and the cases to be included in the study were identified. Averages were provided with standard deviation.

\section{Data collection tools}

The records of patients admitted to Adiyaman Training and Research Hospital with suspected COVID-19 were analyzed. During the analysis, demographic information laboratory, radiological and clinical findings were taken into consideration.

\section{Data analysis}

COVID-19-related laboratory (sedimentation, CRP, lymphocyte, white blood cell) and radiological findings and sociodemographic information (age, gender) of registered patients were made use of. The data obtained from the data collection form was performed using SPSS 22. Descriptive statistics were identified using figures and percentages. Relationship between categorical variables were analyzed using the Chisquare and Fischer's exact Chi-square test. Kruskall wallis and mann whitney $u$ tests were used in comparing the averages. Correlation analysis was performed to determine the between some variables. The results were evaluated in a confidence interval of $95 \%$ and $p<0.05$ was considered significant.

\section{Ethical aspect of the research}

The ethical approval was received from the non-clinical research ethics committee of Adiyaman University (approval no: 2020/7-44).

\section{RESULTS}

$70.6 \%$ of the cases in the study were male and their average age was $41.07 \pm 18.79$. $60 \%$ of hospitalized patients were men which were significantly higher than women $(p<0.05)$. The rate of those who were in an overall good condition was $90 \%$. СТ was performed on $30.8 \%$ of the cases. $19.5 \%$ of the cases were diagnosed with pneumonia as a result of the CT. COVID 19 was the most common diagnosis as a result of CT (11.0\%).

The median age of the cases covered by the study was 37 . The median age of PCR-positive patients was 44.5, and the median age of those receiving intensive care was $65.61 .3 \%$ of PCRpositive cases were male and 59\% were inpatient (Table 1, Table 2).

The duration of hospital stay of PCR-positive patients was significantly higher for those diagnosed with pneumonia, those with poor general condition and those who are intubated (Table 2). The median hospital stay was 7 days, and the median hospital stay for intensive care patients was 8.5 days.

The mean values of CRP, WBC and D-dimer of the cases were $3.79 \pm 5.92,9.47 \pm 4.92,1084.96 \pm 1526.19$, respectively (Table 3 ). A correlation was found between the duration of hospital stay and age, CRP, WBC, D-dimer and lymphocyte (Table 4). 


\begin{tabular}{|c|c|c|c|c|c|c|}
\hline & \multicolumn{2}{|c|}{ PCR + } & \multicolumn{2}{|c|}{ PCR - } & \multirow{2}{*}{$\begin{array}{c}\text { Total } \\
\mathbf{n}\end{array}$} & \multirow[b]{2}{*}{ p } \\
\hline & $\mathbf{n}$ & $\%$ & $n$ & $\%$ & & \\
\hline \multicolumn{7}{|l|}{ Gender } \\
\hline Male & 38 & 61.3 & 212 & 72.6 & 250 & \multirow{2}{*}{$\begin{array}{c}p>0.05 \\
X^{2}=3.154\end{array}$} \\
\hline Female & 24 & 38.7 & 80 & 27.4 & 104 & \\
\hline \multicolumn{7}{|l|}{ Hospitalization } \\
\hline Outpatient & 8 & 12.9 & 246 & 84.2 & 254 & \multirow{3}{*}{$\begin{array}{c}p<0.01 \\
X^{2}=134.498\end{array}$} \\
\hline Ward patient & 46 & 74.2 & 32 & 11 & 78 & \\
\hline Intensive care & 8 & 12.9 & 14 & 4.8 & 22 & \\
\hline \multicolumn{7}{|l|}{ Age } \\
\hline 0-14 years & 7 & 11.3 & 1 & 0.3 & 8 & \multirow{4}{*}{$\begin{array}{c}p<0.01 \\
X^{2}=33.242\end{array}$} \\
\hline $15-49$ years & 29 & 46.8 & 202 & 69.2 & 231 & \\
\hline 50-64 years & 14 & 22.6 & 51 & 17.5 & 65 & \\
\hline $65+$ & 12 & 19.3 & 38 & 13 & 50 & \\
\hline \multicolumn{7}{|l|}{ CT } \\
\hline $\mathrm{N} / \mathrm{Ab}$ & 15 & 24.2 & 230 & 78.8 & 245 & \multirow{5}{*}{$\begin{array}{c}p<0.01 \\
X^{2}=73.608 \\
\text { fisher }\end{array}$} \\
\hline Covid & 18 & 29.0 & 21 & 7.2 & 39 & \\
\hline Viral & 10 & 16.1 & 10 & 3.4 & 20 & \\
\hline Normal & 14 & 22.6 & 21 & 7.2 & 35 & \\
\hline Other & 5 & 8.1 & 10 & 3.4 & 15 & \\
\hline \multicolumn{7}{|l|}{ Pneumonia } \\
\hline Yes & 31 & 50 & 38 & 13 & 69 & \multirow{3}{*}{$\begin{array}{c}p<0.01 \\
X^{2}=44.583\end{array}$} \\
\hline No & 31 & 50 & 254 & 87 & 285 & \\
\hline Total & 62 & & 292 & & & \\
\hline
\end{tabular}

${ }^{b}$ the reason for the difference

\begin{tabular}{|c|c|c|}
\hline & Mean & $\mathbf{p}$ \\
\hline \multicolumn{3}{|l|}{ Ward } \\
\hline Outpatient & $0 \pm 0$ & \multirow{3}{*}{$\begin{array}{c}\mathrm{p}<0.001 \\
\text { U:302 } \\
\text { (outpatient were excluded) }\end{array}$} \\
\hline Ward patient & $9.24 \pm 6.40$ & \\
\hline Intensive care & $22 \pm 9,25$ & \\
\hline \multicolumn{3}{|l|}{ Gender } \\
\hline Male & $10.55 \pm 9.65$ & \multirow{2}{*}{$\begin{array}{c}U=411.500 \\
p>0.05\end{array}$} \\
\hline Female & $7.50 \pm 5.31$ & \\
\hline \multicolumn{3}{|l|}{ According to $\mathrm{CT}$} \\
\hline Yes & $12.48 \pm 9.74$ & \multirow{2}{*}{$\begin{array}{c}U=411.500 \\
p>0.05\end{array}$} \\
\hline No & $7.07 \pm 3.87$ & \\
\hline \multicolumn{3}{|l|}{ Pneumonia } \\
\hline Yes & $13.13 \pm 9.68$ & \multirow{2}{*}{$\begin{array}{l}p<0.01 \\
U=239.0\end{array}$} \\
\hline No & $5.61 \pm 4.27$ & \\
\hline \multicolumn{3}{|c|}{ General condition } \\
\hline Good & $6.90 \pm 4.62$ & \multirow{3}{*}{$\begin{array}{c}\mathrm{p}<0.001 \\
\mathrm{X} 2=14.548 \\
\mathrm{KW}\end{array}$} \\
\hline Moderate & $13.17 \pm 5.19$ & \\
\hline Poor & $26.17 \pm 13.92$ & \\
\hline \multicolumn{3}{|l|}{ Intubation } \\
\hline Yes & $26.17 \pm 13.92$ & \multirow{2}{*}{$\begin{array}{c}\mathrm{p}<0.001 \\
\mathrm{U}: 50.0\end{array}$} \\
\hline No & $7.57 \pm 5.03$ & \\
\hline \multicolumn{3}{|l|}{ Age groups } \\
\hline $0-14$ & $8.86 \pm 1.57$ & \multirow{4}{*}{$\begin{array}{c}\mathrm{p}>0.05 \\
X 2=4.411 \\
\mathrm{KW}\end{array}$} \\
\hline $15-49$ & $6.83 \pm 4.85$ & \\
\hline $50-64$ & $12.79 \pm 13.33$ & \\
\hline 65 and over & $11.83 \pm 8.65$ & \\
\hline
\end{tabular}

\section{Table 3. Comparison of some laboratory averages with certain conditions.}

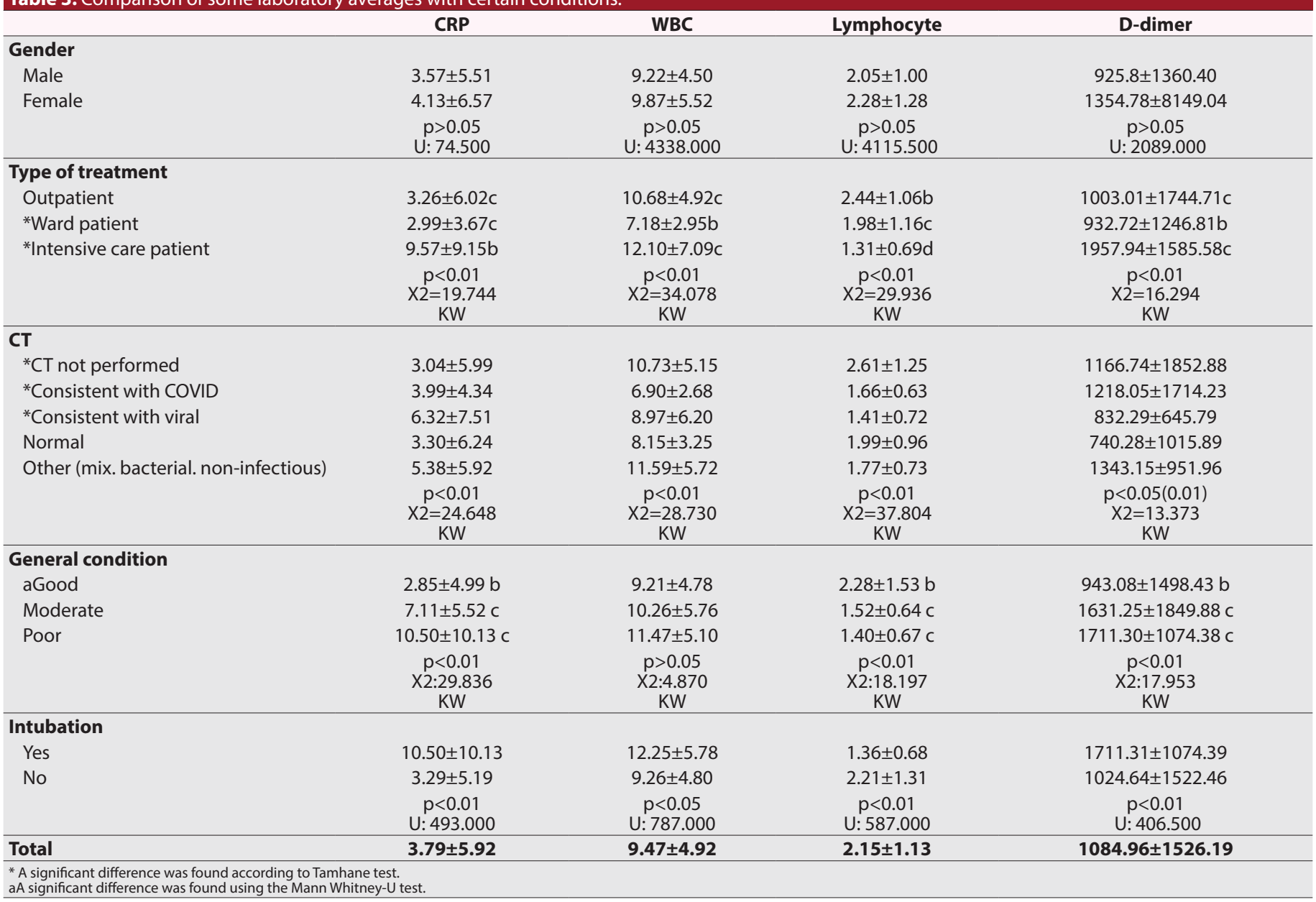




$\begin{aligned} & \text { Table 4. The examination of the correlation of hospitalization status with } \\
& \text { age and some laboratory findings }\end{aligned}$
\begin{tabular}{lcc} 
& $\mathbf{r}$ & $\mathbf{p}$ \\
\hline Age & $\mathrm{r}=0.25$ & $\mathrm{p}<0.01$ \\
CRP & $\mathrm{r}=0.243$ & $\mathrm{p}<0.01$ \\
D-Dimer & $\mathrm{r}=0.141$ & $\mathrm{p}<0.01$ \\
WBC & $\mathrm{r}=-0.343$ & $\mathrm{p}<0.01$ \\
Lymphocyte & $\mathrm{r}=-0.323$ & $\mathrm{p}<0.01$ \\
\hline
\end{tabular}

\section{DISCUSSION}

In our study, $61.3 \%$ of the PCR-positive cases were men. It was found that $75 \%$ of COVID-19 patients to be men; ${ }^{[8]}$ while another study stated the rate of men to be $49 \% .{ }^{[9]}$ Although these studies support our finding that COVID-19 is more common among men than women, another study found the number male and female cases to be similar. ${ }^{[10]}$ In our study, the number of men receiving inpatient treatment was considerably higher than women $(p<0.05)$. A study analyzed the rates of hospitalization and reported that men was affected disproportionally. ${ }^{[9]} 58 \%$ of deaths were men. ${ }^{[10]}$ Another study showed that death cases was increasing among men. ${ }^{[10]}$ Although these studies support our finding that men require more hospital care, a study found the rate of hospitalized female patients to be higher than men. ${ }^{[1]}$ Pandemics affect men and women differently. The exposure risk and biological sensitivity may be different due to the other social factors as well as infections, social and economic results and the gender of an individual. ${ }^{[10]}$ Different sample groups or underreporting may be the reasons behind these differences.

In our study, $17.5 \%$ of patients admitted to the hospital with suspected COVID-19 tested positive with PCR. A study conducted with suspected COVID-19 cases, the rate of PCRpositivity was $35 \% .85 .5 \%$ of COVID-19 patients required hospital care. $20 \%$ of the hospitalized patients required intensive care. $70 \%$ of intensive care patients required ventilation.

In our study, the median duration of hospital stay was 7 days. A study found the median value to be 21 days ${ }^{[9]}$ while another study 13 days. ${ }^{[12]}$ Another study found this to be 10 days. ${ }^{[13]}$ In different studies, the duration of hospital stay varies. This duration depends on living conditions in countries, sociodemographic features and healthcare services.

The duration of hospital stay of PCR-positive patients was significantly higher for those diagnosed with pneumonia, those with poor general condition and those who are intubated. This is an expected outcome. ${ }^{[9]}$

In our study, $14.8 \%$ of inpatient PCR-positive patients required mechanical ventilation. In a study conducted at Chicago University, $28.4 \%$ of the patients were intubated. ${ }^{[10]} \mathrm{A}$ study found that approximately $10 \%$ of the patients required mechanical ventilation. ${ }^{[1]]}$ According to a study in Colombia University, $4.4 \%$ of the patients were intubated. ${ }^{[7]}$ The same study noted that $2.3 \%$ of lab-confirmed cases were intubated.
In our study, $46.7 \%$ of PCR-positive patients had CT abnormalities, $62 \%$ of them which were found to be consistent with COVID-19. A study found that CT images of $65 \%$ of patients, who were being followed-up due to COVID-19, had abnormalities and multifocal ground glass opacities were observed in $74 \%$ of these patients. ${ }^{[14]}$

In our study, it was found that D-dimer and CRP averages of patients, who are intubated, have poor general condition and receive intensive care, were significantly higher $(p<0.05)$. A study found high D-dimer to be a risk factor for hospital mortality ${ }^{[15]}$ Another study found a correlation between high D-dimer and disease severity. ${ }^{[16]} A$ study found CRP levels of severe patients to be significantly higher and CRP levels to be associated with mortality. ${ }^{[17]}$ A study found a correlation between mortality and D-dimer, WBC and CRP. ${ }^{[18]}$ Another study found an association between high CRP and disease severity. This is an expected result as CRP is an acute phase reactant. ${ }^{[19]}$ Another study found that lymphocyte was low while age, CRP, WBC and D-dimer were high in patients who lost their lives. ${ }^{[20]}$

In our study, it was found that WBC was significantly higher in those who were in poor general condition, received intensive care, and whose $\mathrm{CT}$ results were consistent with mixed infection $(p<0.05)$. In a study, high WBC was found to be a risk factor in hospital mortality. ${ }^{[15]}$ WBC and D-dimer were significantly higher in patients who lost their lives. In addition, lymphopenia was detected. ${ }^{[15]}$

Our study showed that the duration of stay at hospital increased with increasing age. Another study showed that the disease became more severe with increasing age. ${ }^{[17]}$ With the increase in age, the severity of the disease also increases. ${ }^{[15]}$

A correlation was found between the duration of hospital stay and age, CRP, WBC, D-Dimer and lymphocyte. In various studies, mortality was found to be associated with advanced age, comorbidity, high D-Dimer and CRP and lymphopenia. ${ }^{[15]}$ This study has some limitations. The first limitation is that it was conducted in a single center. Another limitation is the study was conducted based on records.

\section{ETHICAL DECLARATIONS}

Ethics Committee Approval: The ethical approval was received from the non-clinical research ethics committee of Adıyaman University (approval no: 2020/7-44). Necessary permission was obtained from the Ministry of Health and Adiyaman Training and Research Hospital

Informed Consent: Written consent was obtained from all patients who participated in the study and their relatives.

Referee Evaluation Process: Externally peer-reviewed.

Conflict of Interest Statement: The author(s) declared no potential conflicts of interest with respect to the research, authorship, and/or publication of this article.

Financial Disclosure: The authors declared that this study has received no financial support. 
Author Contributions: All of the authors declare that they have all participated in the design, execution, and analysis of the paper, and that they have approved the final version.

\section{REFERENCES}

1. İtil O, Altınışık Ergur G, Köktürk N, Havlucu Y, Akgün M, Aykaç N, eds. COVID-19 Pandemisi ve Sağlığın Sosyal Bileşenleri, Türk Toraks Derneği COVID-19 E-Kitapları Serisi, Haziran.; 2020

2. Seker M, Özer A, Tosun Z, Korkut C, Doğrul M. Covid-19 Pandemi Değerlendirme Raporu.; 2020. Accessed September 16, 2020.

3. Lauer SA, Grantz $\mathrm{KH}, \mathrm{Bi} \mathrm{Q}$, et al. The incubation period of coronavirus disease 2019 (CoVID-19) from publicly reported confirmed cases: Estimation and application. Annals of Internal Medicine. 2020;172(9):577582.

4. Pérez A, Santamaria EK, Operario D, et al. World Health Organization (2020). Report of the WHO-China Joint Mission on Coronavirus Disease 2019 (COVID-19). Vol 5.; 2017. Accessed October 14, 2020.

5. Karaca B. Clinical Findings of the COVID-19 in the Adult Group. J Biotechnol and Strategic Health Res. 2020;1:85-90.

6. Pan A, Liu L, Wang C, et al. Association of Public Health Interventions with the Epidemiology of the COVID-19 Outbreak in Wuhan, China. JAMA. 2020;323(19):1915-1923.

7. Argenzian MG, Bruc SL, Slate CL, et al. Characterization and clinical course of 1000 patients with coronavirus disease 2019 in New York: Retrospective case series. The BMJ. 2020;369.

8. Mardani R, Ahmadi Vasmehjani A, Zali F, et al. Laboratory Parameters in Detection of COVID-19 Patients with Positive RT-PCR; a Diagnostic Accuracy Study. Archives of academic emergency medicine. 2020;8(1):e43.

9. Thai PQ, Toan DTT, Dinh TS, et al. Factors associated with the duration of hospitalization among COVID-19 patients in Vietnam: A survival analysis. Epidemiology and Infection. 2020;148.

10. Hur K, Price CPE, Gray EL, et al. Factors Associated With Intubation and Prolonged Intubation in Hospitalized Patients With COVID-19. Otolaryngology - Head and Neck Surgery (United States). 2020;163(1):170178. doi:10.1177/0194599820929640

11. Halaçli B, Kaya A, Topeli A. Critically ill COVID-19 patient. Turkish Journal of Medical Sciences. 2020;50(SI-1):585-591.

12. Wu Y, Hou B, Liu J, Chen Y, Zhong P. Risk Factors Associated With LongTerm Hospitalization in Patients With COVID-19: A Single-Centered, Retrospective Study. Frontiers in Medicine. 2020;7:315.

13. Karagiannidis C, Mostert C, Hentschker C, et al. Case characteristics, resource use, and outcomes of 10021 patients with COVID-19 admitted to 920 German hospitals: an observational study. The Lancet Respiratory Medicine. 2020;8(9):853-862.

14. To KKW, Tsang OTY, Leung WS, et al. Temporal profiles of viral load in posterior oropharyngeal saliva samples and serum antibody responses during infection by SARS-CoV-2: an observational cohort study. The Lancet Infectious Diseases. 2020;20(5):565-574.

15. Zhou F, Yu T, Du R, et al. Clinical course and risk factors for mortality of adult inpatients with COVID-19 in Wuhan, China: a retrospective cohort study. The Lancet. 2020;395(10229):1054-1062.

16. Petrilli $C$, Jones $S$, Yang J, et al. Factors associated with hospitalization and critical illness among 4,103 patients with COVID-19 disease in New York City. BMJ. Published online April 11, 2020:2020.04.08.20057794.

17. Wang L. C-reactive protein levels in the early stage of COVID-19. Medecine et Maladies Infectieuses. 2020;50(4):332-334.

18. Zhang L, Yan X, Fan Q, et al. D-dimer levels on admission to predict inhospital mortality in patients with Covid-19. Journal of Thrombosis and Haemostasis. 2020;18(6):1324-1329.

19. Mooiweer E, Luijk B, Bonten MJM, Ekkelenkamp MB. C-Reactive protein levels but not CRP dynamics predict mortality in patients with pneumococcal pneumonia. Journal of Infection. 2011;62(4):314-316.

20. Satici C, Demirkol MA, Sargin Altunok E, et al. Performance of pneumonia severity index and CURB-65 in predicting 30-day mortality in patients with COVID-19. Int J Infect Dis 2020;98:84-89. 